\title{
Estimated contributions of primary and secondary organic aerosol from fossil fuel combustion during the CalNex and Cal-Mex campaigns
}

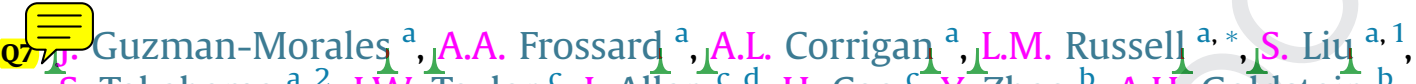

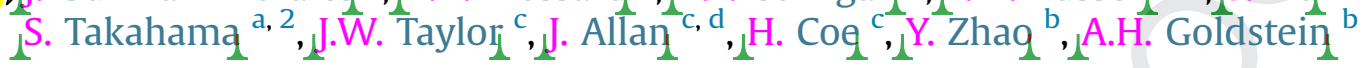 \\ ${ }^{a}$ Scripps Institution of Oceanography, University of California San Diego, La Jolla, CA, USA \\ b Department of Environmental Science Policy and Management, University of California, Berkeley, CA, USA \\ c School of Earth, Atmospheric and Environmental Sciences, The University of Manchester, Manchester, UK \\ ${ }^{\mathrm{d}}$ National Centre for Atmospheric Science, The University of Manchester, Manchester, UK
}

\section{H I G H L I G H T S}

- Fossil fuel emissions contribute from $60 \%$ to $80 \%$ to the ambient particle OM.

- The identification of alkane group peaks by FTIR provides fuel-specific signatures.

- POM and SOM from fossil fuel sources accounted for $16-20 \%$ and $42-62 \%$, respectively.

\section{A R T I C L E I N F O}

\section{Article history:}

Received 22 May 2013

Received in revised form 10 August 2013

Accepted 25 August 2013

\section{Keywords:}

Carbonaceous aerosol particles

Fossil fuel combustion sources

Primary organic aerosol

Secondary organic aerosol

FTIR

\begin{abstract}
A B S T R A C T
Observations during CalNex and Cal-Mex field campaigns at Bakersfield, Pasadena, Tijuana, and on board the R/V Atlantis show a substantial contribution of fossil fuel emissions to the ambient particle organic mass (OM). At least two fossil fuel combustion (FFC) factors with a range of contributions of oxidized organic functional groups were identified at each site and accounted for $60-88 \%$ of the total OM. Additional marine, vegetative detritus, and biomass burning or biogenic sources contribute up to $40 \%$ of the OM. Comparison of the FTIR spectra of four different unburned fossil fuels (gasoline, diesel, motor oil, and ship diesel) with PMF factors from ambient samples shows absorbance peaks from the fuels are retained in organic aerosols, with the spectra of all of the FFC factors containing at least three of the four characteristic alkane peaks observed in fuel standards at 2954, 2923, 2869 and $2855 \mathrm{~cm}^{-1}$. Based on this spectral similarity, we estimate the primary OM from FFC sources for each site to be $16-20 \%$, with secondary FFC OM accounting for an additional $42-62 \%$. Two other methods for estimating primary OM that use carbon monoxide (CO) and elemental carbon (EC) as tracers of primary organic mass were investigated, but both approaches were problematic for the CalNex and Cal-Mex urban sites because they were influenced by multiple emission sources that had site-specific and variable initial ratios to OM. For example, using the $\Delta \mathrm{POM} / \Delta \mathrm{CO}$ ratio of $0.0094 \mu \mathrm{g} \mathrm{ppb} \mathrm{V}{ }^{-1}$ proposed by other studies produces unrealistically high estimates of primary FFC OM of $55-100 \%$.
\end{abstract}

(c) 2013 Elsevier Ltd. All rights reserved.

\section{Introduction}

In California, as well as in much of the rest of the world, the organic fraction of particles constitutes $10-70 \%$ of the mass of fine aerosol (Turpin et al., 2000), but the quantity and composition of

\footnotetext{
* Corresponding author.

E-mail address: Imrussell@ucsd.edu (L.M. Russell).

1 Now at Earth System Observations, Los Alamos National Laboratory, Los Ala$\operatorname{mos}, \mathrm{N} \overline{\bar{\equiv}}$.

2 Now依 Atmospheric Particle Research Laboratory, APRL/IEE/ENAC, École PolyQ1 technique Fédérale de Lausanne (EPFL), Lausanne, $\mathrm{CH}$, Switzerland.
}

the man-made contribution to atmospheric organic particles are not well characterized. Russell et al. (2011) used the spectral signatures of Fourier transform infrared (FTIR) spectroscopy measurements of carbonaceous particle mass to show that fossil fuel combustion (FFC) accounts for $62 \%$ of organic mass but ranges from $35 \%$ to $93 \%$, although the sampled locations were biased toward coastal and marine locations. In highly populated urban regions such as southern California, most of the submicron organic mass $(\mathrm{OM})$ is attributable to emissions of fossil fuel combustion, in particular to motor vehicles (Hayes et al., 2013; Liu et al., 2012).

Fossil fuel combustion processes produce organic compounds that can form particles before emission (primary organic mass,

1352-2310/\$ - see front matter (c) 2013 Elsevier Ltd. All rights reserved.

http://dx.doi.org/10.1016/j.atmosenv.2013.08.047 
POM) and after emission (secondary organic mass, SOM) into the atmosphere. Models tend to track primary and secondary carbonaceous particles separately because of their different production mechanisms, but observations often have a difficult time separating these components, as some are chemically similar (Cass, 1998). For example, the loss of some mass of the carbonaceous particles due to increased volatility (Robinson et al., 2007) or reactivity (Molina et al., 2004) in changing ambient conditions means that using tracers will overestimate the primary OM associated with some sources. In addition, for some sources carbonaceous particles are accompanied by VOCs that can later add OM to the particle phase as secondary carbonaceous components. SOM has been estimated in several urban, polluted environments (de Gouw et al., 2005; Johnson et al., 2006; Takegawa et al., 2006; Volkamer et al., 2006), but there is significant disparity between laboratory simulations and SOM observations in areas with high anthropogenic activity (Gentner et al., 2012).

Several methods have been used to separate the contributions of POM and SOM to OM based on either temporal variation or the oxygenated OM composition (Liu et al., 2011). Comparisons of multiple methods have shown good agreement in some regions (Liu et al., 2011, 2012; Zhao et al., 2013) but such agreement may depend on local conditions since the types and mixtures of sources are different in each location as is their atmospheric processing.

Characterizing the main sources for POM and SOM in the California region was a major focus of the CalNex and Cal-Mex campaigns at the ground sites at Bakersfield, Pasadena, and Tijuana as well as for the shipboard observations on the R/V Atlantis during May and June of 2010. To assess the degree to which these short campaigns are representative of the region and the summer season, we compare the organic carbon (OC) measurements from nearby monitoring sites of the IMPROVE and CARB networks. To separate primary and secondary contributions of fossil fuel combustion emissions (primarily from motor vehicles and shipping) to $\mathrm{OM}$, we use organic functional group measurements to provide upper and lower bounds on the uncertainties associated with this separation. The results are used to evaluate the extent to which the relationship of OM components to $\mathrm{CO}$ and of OC components to EC can be used as indicators of primary and secondary organic sources.

\section{Methods}

\subsection{OM, OC, EC, and CO measurements}

The CalNex and Cal-Mex projects included three ground sites at Bakersfield ( $\left.35^{\circ} 21^{\prime} 0^{\prime \prime} \mathrm{N}, 118^{\circ} 58^{\prime} 12^{\prime \prime} \mathrm{W}\right)$, Pasadena $\left(34^{\circ} 8^{\prime} 13^{\prime \prime} \mathrm{N}\right.$, $\left.118^{\circ} 7^{\prime} 28^{\prime \prime} \mathrm{W}\right)$, and Tijuana ( $\left.32^{\circ} 29^{\prime} 55^{\prime \prime} \mathrm{N}, 116^{\circ} 56^{\prime} 25^{\prime \prime} \mathrm{W}\right)$. The sites are shown in Fig. 1. Measurements took place from 15 May to 30 June 2010 at Bakersfield and Tijuana, while at Pasadena the sampling period was 15 May to 16 June 2010. Coastal measurements were collected on board the R/V Atlantis from 15 May to 6 June 2010. Ambient particles were sampled at $18 \mathrm{~m}$ above sea level through a heated mast that controlled the relative humidity $(\mathrm{RH})$ of the air masses to $60 \%$, which partially dried the aerosol. Sector control for the flow was used to prevent sampling of emissions directly from the R/V Atlantis. The cruise track followed the California coastline and the Sacramento-San Joaquin River delta, with sampling in proximity to Los Angeles, Oxnard, Monterey Bay, San Francisco, and Sacramento.

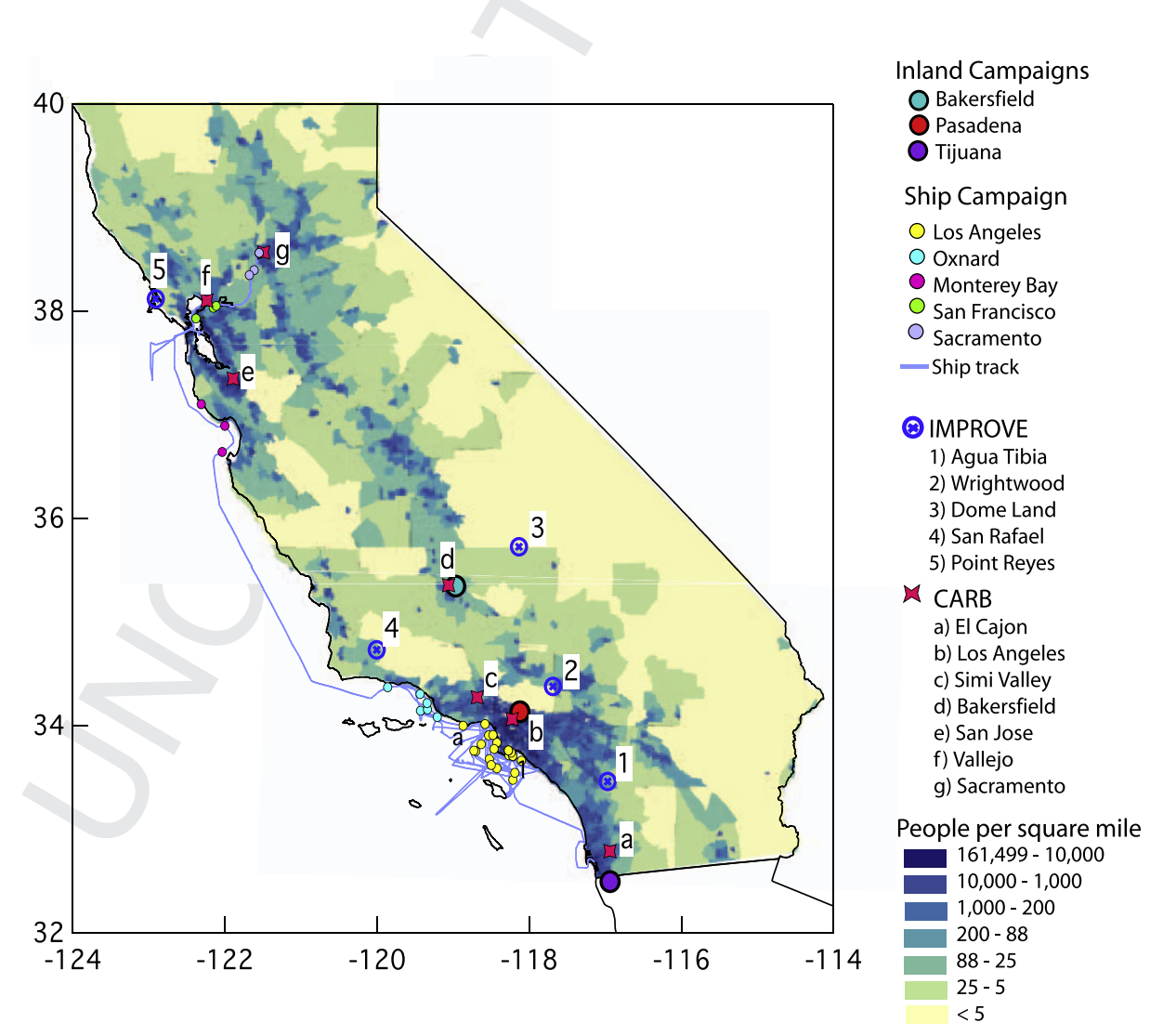

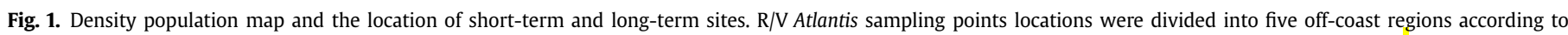

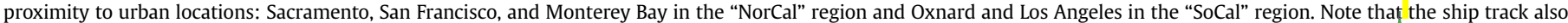

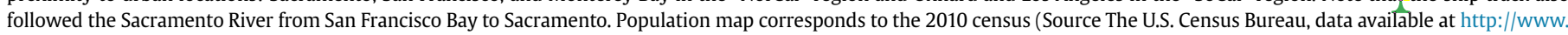
census.gov/2010census/). 
For comparison with the CalNex and Cal-Mex sites, we identified five IMPROVE (Interagency Monitoring of Protected Visual Environments, http://views.cira.colostate.edu/web/DataWizard/) and six CARB (California Air Resources Board, http://www.arb.ca. gov/aqmis2/aqmis2.php) sites with long-term measurements in nearby rural and urban locations. These sites, along with the distance to the intensive CalNex and Cal-Mex sites, are listed in Table 1 and shown on Fig. 1. For each intensive site, we identified both a nearby "background" site in a rural location from the IMPROVE network and a nearby "urban" site from the CARB network. At both IMPROVE and CARB sites, OC concentrations were measured in particles less than $2.5 \mu \mathrm{m}$ in a 24 -h basis every $3-6$ days. The OC sampling and analysis protocols for the IMPROVE and CARB sites use the Thermal Optical Reflectance (TOR) method (with detailed protocols at ftp://ftp.arb.ca.gov/aqd/ aqded/web2011/pm25_speciation_desc.pdf, and http://vista.cira. colostate.edu/improve/Publications/OtherDocs/

IMPROVEDataGuide/IMPROVEDataGuide.pdf).

For the CalNex and Cal-Mex measurements at Tijuana, Bakersfield and R/V Atlantis, particles were collected through a single 1$\mu \mathrm{m}$ sharp-cut cyclone (SCC 2.229 PM1, BGI Inc., Waltham, MA) on $37 \mathrm{~mm}$ Teflon filters (Pall Corp., Ann Arbor, MI). The filters were loaded with constant airflow rate for $3 h z^{12} h$. At Pasadena, similar sampling was carried out using a $2.5 \mu \mathrm{m}$ sharp-cut cyclone during $23 \mathrm{~h}$ each day. After particle collection, the samples from all of the locations were sealed and stored below $0{ }^{\circ} \mathrm{C}$ to avoid evaporative losses before FTIR and X-ray fluorescence (XRF) analysis.

Four types of liquid fuels were selected to serve as standards. Gasoline, diesel, and motor oil were purchased in January 2012 at a Mobil gas station in La Jolla, California, and low-sulfur ship diesel was sampled from the tanks of the R/V Point Sur in July 2011. Each sample was atomized and collected on three $37 \mathrm{~mm}$ replicate Teflon filters.

Filters were scanned before and after aerosol loading by transmission FTIR spectroscopy using a Tensor 27 spectrometer with DTGS detector (Bruker Optics Inc., Billerica, MA; OPUS software). Initial spectra are obtained prior to sampling. After sampling, each ambient spectrum was calculated as the difference of the final and initial scan spectra. The $\mathrm{OM}$ and $\mathrm{OC}$ concentration of organic functional groups were determined using an automated baselining and peak-fitting algorithm (Day et al., 2010; Russell et al., 2009; Takahama et al., 2013b) that quantifies alkane (CH), hydroxyl (C$\mathrm{OH})$, carboxylic acid $(\mathrm{COOH})$, non-acid carbonyl $(\mathrm{C}=\mathrm{O})$, amine $(\mathrm{C}-$ $\left.\mathrm{NH}_{2}\right)$, and organonitrate $\left(\mathrm{C}-\mathrm{ONO}_{2}\right)$ functional group concentrations based on the intensity of their characteristic infrared absorption band. Samples were analyzed for wavenumbers from 400 to $4000 \mathrm{~cm}^{-1}$ with a resolution of $4 \mathrm{~cm}^{-1}$. Baselining and standard compound calibrations for each organic functional group reported are provided in Gilardoni et al. (2007) and Liu et al. (2009). For the fuel standards, the average FTIR spectra of the three filters collected for each was used.

Refractory carbon concentrations were measured as a proxy for elemental carbon at the Tijuana and Pasadena sites. An 8-channel Single Particle Soot Photometer (SP2; Droplet Measurement Technologies, Inc.) was calibrated from the response to atomized, sizeselected Aquadag (Aqueous Deflocculated Acheson Graphite, Acheson Inc., USA) particles in aqueous solution. The measurements were processed with PAPI, Probe Analysis Package for Igor, software modified from the work by Subramanian et al. (2010). The mass-based lower detection limit is $\sim 0.7 \mathrm{fg}$, or $90 \mathrm{~nm}$ in massequivalent diameter (Schwarz et al., 2010). The SP2 measurements at the Pasadena supersite were using a 4-channel version of the instrument, calibrated using glassy carbon spheres (Type II, Alfa Aesar, Ward Hill, MA, USA) in the manner described by Liu et al. (2010) and McMeeking et al. (2010). Comparison to the NOAA SP2 calibrated with fullerene soot, showed agreement to within $10 \%$. The SP2 also has two avalanche photodiode (APD) scattering detectors, which were calibrated with polystyrene latex spheres (PSLs; Duke Scientific, now Thermo Fisher Scientific, Waltham, MA, USA). This deployment and data analysis and quality assurance methods is presented in more detail in Taylor (2013).

Carbon monoxide concentrations were measured at nearby monitoring sites in Tijuana (at La Mesa) and Los Angeles (at CARB site). At the Bakersfield location carbon monoxide was measured from the top of the tower using a gas filter correlation infrared spectrometer (Teledyne, API M300EU2).

\section{Results and discussion}

\subsection{Comparison of CalNex and Cal-Mex OC with monitoring sites}

At all four CalNex and Cal-Mex campaign sites discussed here ( $\mathrm{R} /$ V Atlantis, Tijuana, Pasadena, and Bakersfield), the measured OC was above the nearby rural and below the urban OC concentrations from the long-term monitoring sites. Fig. 2 shows the comparison of the OC measurements at R/V Atlantis, Tijuana, Pasadena, and Bakersfield with the urban and rural monitoring sites. The urban sites typically have OC concentrations higher than the corresponding rural sites by factors of $2-5$. Interestingly, the differences in OC concentrations are lower during the summer. This is consistent with a larger contribution from both biogenic and transported secondary $O C$ in the summer and a smaller contribution from residential woodburning sources.

Table 1

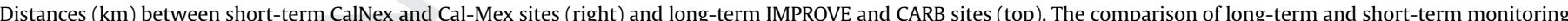

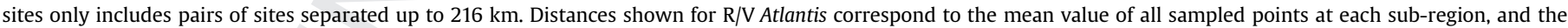
minimum and maximum distances of the sampled points are shown in parentheses.

\begin{tabular}{|c|c|c|c|c|c|c|c|c|c|}
\hline \multirow{2}{*}{\multicolumn{2}{|c|}{$\frac{\text { Distance }(\mathrm{km})}{\text { CalNex Cal-Mex }}$}} & \multicolumn{3}{|l|}{ IMPROVE } & \multicolumn{5}{|l|}{ CARB } \\
\hline & & \multirow{2}{*}{$\frac{\text { Wright-wood }}{101(87-118)}$} & San Rafael & \multirow[t]{2}{*}{ Point Reyes } & \multirow{2}{*}{$\frac{\text { Los }_{\triangle} \text { angeles }}{45(65-29)}$} & \multirow{2}{*}{$\frac{\text { Simi valley }}{64(30-98)}$} & \multirow{2}{*}{$\frac{\text { San Jose }}{-}$} & \multirow{2}{*}{$\begin{array}{l}\text { Vallejo } \\
-\end{array}$} & \multirow{2}{*}{$\begin{array}{l}\text { Sacramento } \\
-\end{array}$} \\
\hline R/V Atlantis* & Los Angeles & & $181(216-133)$ & & & & & & \\
\hline & Oxnard & 162 (144-199) & $79(43-103)$ & - & $113(154-91)$ & $71(53-109)$ & - & - & - \\
\hline & Monterey Bay & - & - & $155(124-182)$ & - & - & $59(79-47)$ & - & - \\
\hline & San Francisco & - & - & $64(51-71)$ & - & - & - & $16(12-23)$ & - \\
\hline & Sacramento & - & - & $119(111-129)$ & - & - & - & - & $19(5-29)$ \\
\hline & & Agua Tibia & & & El Cajon & & & & \\
\hline \multirow{2}{*}{\multicolumn{2}{|c|}{ Tijuana }} & 107 & & & 32 & & & & \\
\hline & & Wrightwood & & & Los Angeles & & & & \\
\hline \multirow{2}{*}{\multicolumn{2}{|c|}{ Pasadena }} & 48 & & & 12 & & & & \\
\hline & & San Rafael & & Dome Land Wilderness & Bakersfield & & & & \\
\hline \multicolumn{2}{|l|}{ Bakersfield } & 117 & \multicolumn{2}{|c|}{186} & 8 & & & & \\
\hline
\end{tabular}


The R/V Atlantis measured daily mean OC concentrations between $2 \mu \mathrm{g} \mathrm{C} \mathrm{m}{ }^{-3}$ and $0.3 \mu \mathrm{g} \mathrm{C} \mathrm{m}{ }^{-3}$ with a very uniform oxygen to carbon ratio $(\mathrm{O} / \mathrm{C})$ of 0.46 along its track. The highest $\mathrm{OC}$ concentrations were observed when the ship track was close to coastal southern California, and similar to Los Angeles and Simi Valley sites measurements (Fig. 2). As the ship moved northward, OC concentrations decreased to values below $0.6 \mu \mathrm{g} \mathrm{C} \mathrm{m}{ }^{-3}$ similar to the measurements at Vallejo and Sacramento sites during that period. The small difference in OFG (organic functional group) composition between southern California and northern California indicates that the two regions may have had similar mixtures of sources types. The significantly higher mass concentration in the more southern region indicates that the dilution of the OM loading in northern California was likely due to cleaner air brought from northwest offshore winds over the ocean.

The Cal-Mex measurements at Tijuana in Parque Morelos are comparable with both long-term sites, except from May 29 to June 7 when high local biomass burning emissions were detected. The
Agua Tibia (IMPROVE) and El Cajon (CARB) sites had similar OC concentrations during the summer. The similarity of OC concentrations among the three sites is consistent with the findings of Takahama et al. (2013b) that the majority (up to $80 \%$ ) of the OM measured at Tijuana during Cal-Mex was transported from the Los Angeles area rather than produced by local sources (at least $20 \%$ of the total OM). The large contribution of transported OC also explains the similarity between the rural site at Agua Tibia and the urban site at El Cajon. In contrast, the wintertime concentrations at these two sites are very different, with El Cajon OC concentrations of more than $8 \mu \mathrm{g} \mathrm{C} \mathrm{m}^{-3}$ exceeding those of Agua Tibia by a factor of 10 or more in December.

The OC concentrations at the CalNex Pasadena site $\left(3.6 \pm 1.3 \mu \mathrm{g} \mathrm{m}^{-3}\right)$ were very similar in magnitude to the measurements at the long-term Los Angeles site. Daytime sea breeze transports emissions from the southwest to the northeast with an average transport time of emissions from Los Angeles to Pasadena of $3.25 \mathrm{~h}$, making the consistency in OC concentrations between Los

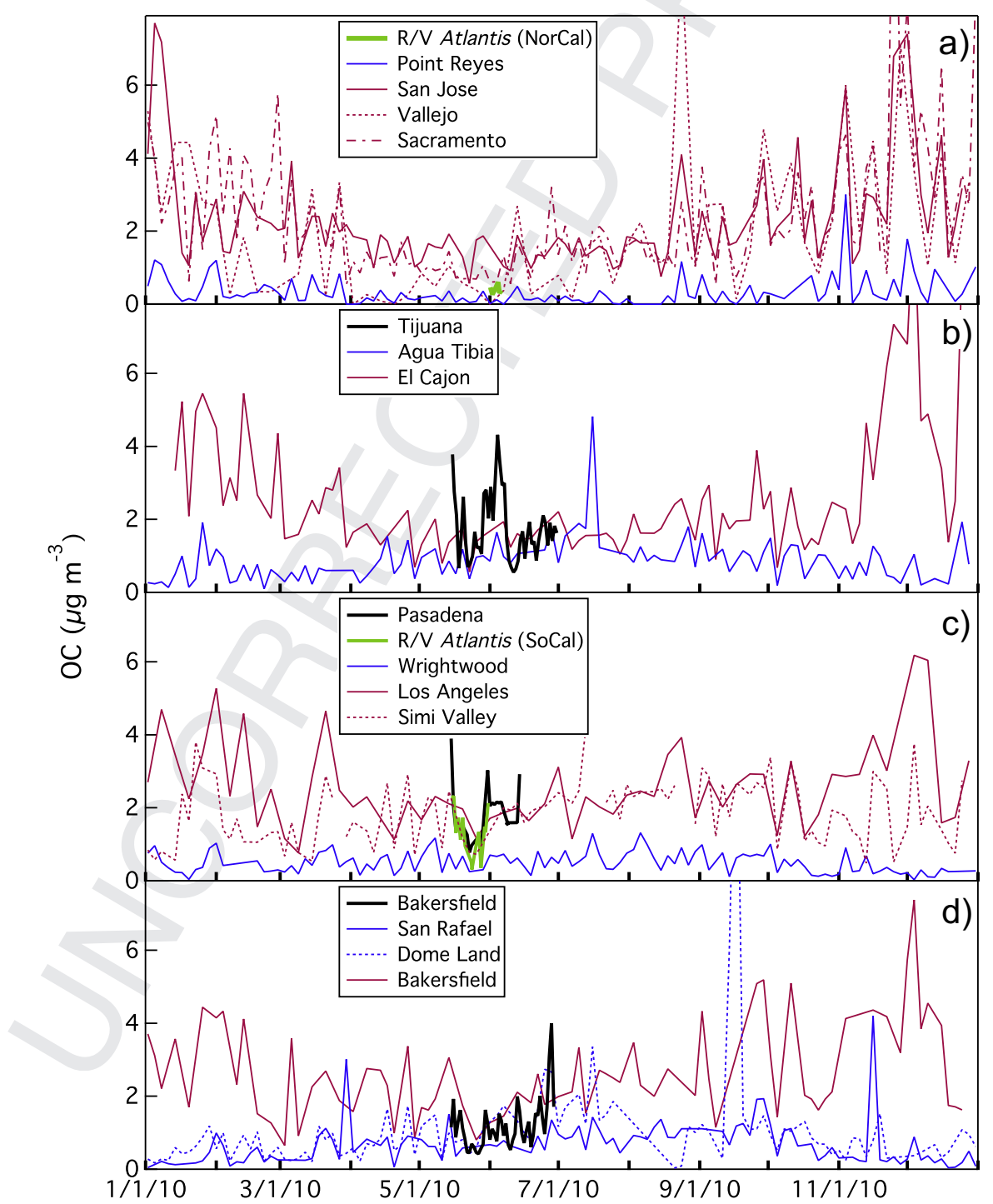

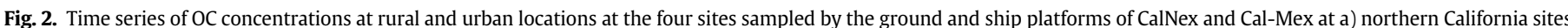

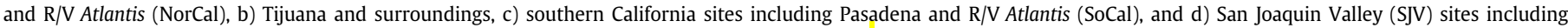

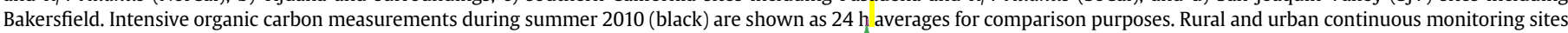

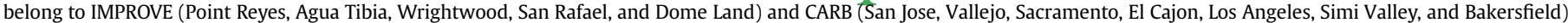

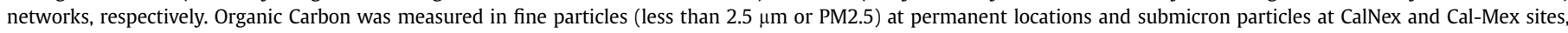
except for Pasadena where only fine particles (PM2.5) were collected. 
Angeles and Pasadena reasonable (Hayes et al., 2013). The emissions in the Basin exit through passes in the San Gabriel (El Cajon Pass) and San Bernadino Mountains (Banning Pass) (Lu and Turco, 1995). Given that Wrightwood is located in the San Gabriel Mountains and is shielded from the high OC source regions of the Los Angeles Basin and its outflow pollution, such low OC concentrations are to be expected. The rural Wrightwood site had considerably lower OC concentrations than either Pasadena or Los Angeles, on average 5-10 times lower. Seasonal differences in OC were observed at the Los Angeles monitoring site, with higher concentrations in winter than in summer. One would expect similar seasonal differences at Pasadena, given the airflow patterns in the LA Basin. Wrightwood had fairly constant OC throughout the year, indicating no substantial biogenic or residential (or agricultural) burning sources.

The urban and rural OC concentrations near the CalNex Bakersfield site differed by less than a factor of 2 in summer 2010, with Dome Land and San Rafael rural concentrations of about $1 \mu \mathrm{g} \mathrm{C} \mathrm{m}{ }^{-3}$ and Bakersfield CARB site concentrations of $2 \mu \mathrm{g} \mathrm{C} \mathrm{m}{ }^{-3}$. Similar to Tijuana, wintertime OC concentrations showed a larger difference between urban and rural OC, consistent with lower contributions from local urban sources during summertime.

\subsection{Factor analysis of FTIR spectra at CalNex and Cal-Mex sites}

To assess the major sources that contribute to the total organic aerosol composition, the apportionment of measured OM using positive matrix factorization (PMF) (Paatero and Tapper, 1994) was determined for each site (R/V Atlantis, Tijuana, Pasadena and Bakersfield). This approach provides a framework that separates the organic mass into separate factors with distinctive functional group composition and magnitude. The complete description of PMF solutions and their association with specific sources is provided in Takahama et al. (2013a) and Liu et al. (2012) for Tijuana and Bakersfield, and in the Supplemental material for R/V Atlantis and Pasadena.

Five main source categories were identified based on factor spectra and organic composition similarities: less and more oxidized fossil fuel combustion (FFC), marine, vegetative detritus, and mixed FFC with biomass burning or biogenic SOM (Fig. 3).

The baselined FTIR spectra were separated by PMF, and ammonium is largely associated with the vehicular fuel factors in most of the PMF factor solutions that were produced. For comparison of only the organic functional group contributions, Fig. 3 also shows the factor spectra with the ammonium contribution removed.

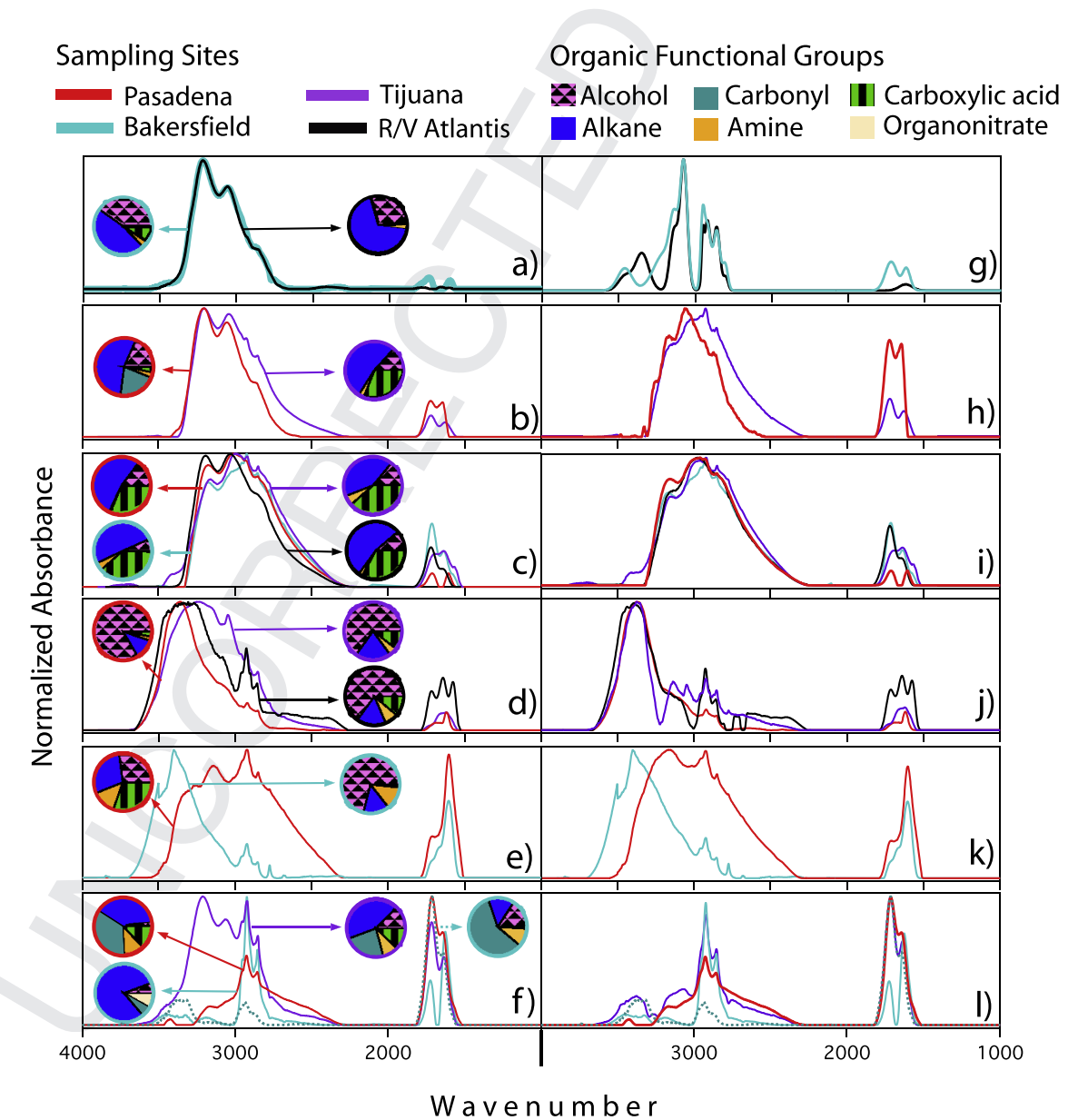

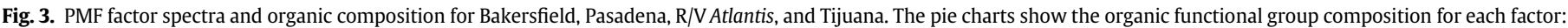

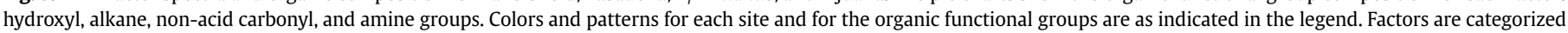

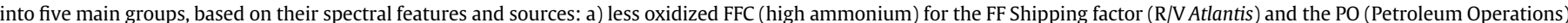

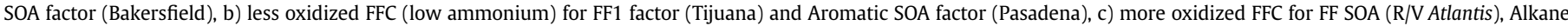

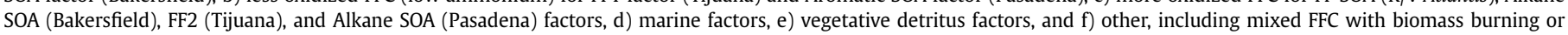

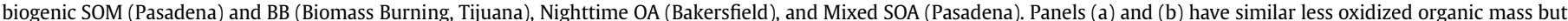

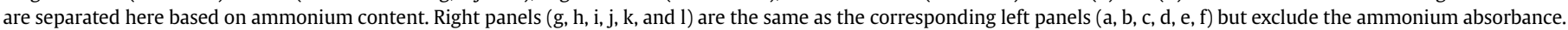
For panel g, the reconstructed spectra are shown. (For interpretation of the references to color in this figure legend, the reader is referred to the web version of this article.) 
Two or more factors were identified as related to FFC based on both 1) the temporal correlations of the factor time series to measured elemental or molecular tracers of fossil fuel emissions or to PMF factors (from co-located online organic measurements) that were identified as associated with FFC and 2) the chemical similarities of the OFG composition and the FTIR spectra to PMF factors identified at other locations (Russell et al., 2011). At Tijuana, the FF1 and FF2 factors were identified as FFC related because of their correlation to higher time resolved ACSM (Aerosol Chemical Speciation Monitor) factors that had good correlations with benzene, toluene and heavier aromatic compounds (C8 and C9) (Takahama et al., 2013a). The FF1 factor was also correlated to V and S, suggesting some influence from shipping. Shipping was identified as the likely source of the small FF Shipping factor on the R/V Atlantis, since it had weak correlations to ammonium and sulfate but a weak anti-correlation to radon (a tracer for coastal influence). The FF SOA factor on the R/V Atlantis was identified as FFC-related and secondary because of its strong correlation to sulfate and oxalate (Sorooshian et al., 2006), but the correlation to radon indicated the more coastal origins of this OM (Hawkins et al., 2010). At Bakersfield, oxidation products of alkanes and polycyclic aromatic hydrocarbons were used as molecular tracers for the identification of the Alkane SOA and Aromatic SOA factors (Liu et al., 2012). Petroleum Operation SOA factor, denoted as PO SOA, at Bakersfield was correlated to V and S, which indicated the use of fuel that is similar to ship diesel in that it had not been refined but from back trajectories was identified with drilling processes that burn crude oil. In Pasadena, the Alkane SOA and Aromatic SOA factors were correlated with the sum of the first two FFC-related AMS factors (HOA and SV-OOA) and with the third FFC-related AMS factor (LV-OOA), respectively. The sum of the HOA and SV-OOA factors was associated with primary and "fresh" secondary combustion products because it was found to vary with BC, benzene, and EC, as well as with acetaldehyde and odd oxygen (Hayes et al., 2013). The LV-OOA factor was more oxidized and correlated mildly to sulfate, nitrate, and ammonium, consistent with a photochemically processed FFC source. Factors that were not primarily associated with FFC at each site included the Marine factor on the R/V Atlantis (see Supplemental material), Mixed SOA (including cooking as well as some FFC sources), Vegetative Detritus, and Marine factors at Pasadena (see Supplemental material), Vegetative Detritus and Nighttime OA factors at Bakersfield (Liu et al., 2012), and Biomass Burning (referred as BB factor) and Marine factors at Tijuana (Takahama et al., 2013a).

The multiple fossil-fuel-related factors had varying contributions from oxidized organic functional groups (non-acid carbonyl, hydroxyl, and carboxylic acid groups). The factors with lower oxidized organic functional groups concentrations may include both POM and first generation secondary OM (Fig. 3, panels a and b). Comparison of the left panels in Fig. 3 shows the large contribution of ammonium to the less oxidized FFC factors at Bakersfield and R/V Atlantis. The second FFC factor with a higher contribution of oxidized organic functional groups is dominated by secondary organic mass (panel c). An additional FFC factor dominated by SOM is observed only at Bakersfield (Fig. 3, panels f and l). This factor is attributed to oxidation products of aromatic hydrocarbons because of its large non-acid carbonyl content and its correlation with gaseous oxidation products of polycyclic aromatic compounds (Liu et al., 2012).

The contribution of organic mass related to total FFC sources accounts for more than half of the total $\mathrm{OM}$ in the inland and coastal sites (60-88\%). Nevertheless, the relative contribution of two types of fossil fuel combustion sources varies considerably among R/V Atlantis, Tijuana, Pasadena and Bakersfield sites, with the less oxidized FFC factors accounting for $8-42 \%$ and the more oxidized FFC factors accounting for $17-80 \%$ of the total OM. This wide range indicates that the $\mathrm{OM}$ contributions from fossil fuel combustion sources differ substantially by location. The composition of the more oxidized FFC factors are fairly consistent among all of the sites with $50 \%$ alkane, $12 \%$ hydroxyl, 35\% carboxylic acid, and $4 \%$ amine groups by mass on average. The small range of slopes in the plot of the alkane group $(\mathrm{CH})$ fraction to the sum of the oxidized groups (acid and non-acid $\mathrm{C}=\mathrm{O}+\mathrm{C}_{-} \mathrm{OH}$ ) fractions of OM shows a narrow range from 0.8 to 1.3 as shown in Fig. 4a, indicating a fairly consistent composition among the four CalNex and Cal-Mex platforms with FTIR measurements (R/V Atlantis, Tijuana, Pasadena, and Bakersfield). Fig. 4a is analogous to a "van Krevelen diagram," in that it provides the relationship between aliphatic functional groups and oxidized organic functional groups. The ratio of hydroxyl to acid and non-acid carbonyl functional groups also has a limited range from 0.2 to 0.5 (triangles in Fig. $4 \mathrm{~b}$ ), which is consistent with the similarities in the OFG shown in panel (c) of Fig. 3 despite local differences in oxidation conditions and primary source contributions. In contrast, there are significant composition differences among less oxidized FFC factors reflecting the different characteristic emission mixtures and processing conditions for the different sites.

The Marine factor identified by FTIR PMF is attributed to organic mass derived from ocean sources. The Marine factors are dominated by hydroxyl functional groups (70\%) and have the highest values of hydroxyl $\left(\mathrm{C}_{7} \mathrm{OH}\right)$ to (acid and non-acid) carbonyl $(\mathrm{C}=\mathrm{O})$ group ratios (6.5-30, diamonds in Fig. 4b). The anti-correlation of the $\mathrm{C}_{2} \mathrm{OH} / \mathrm{OM}$ to total $\mathrm{C}=\mathrm{O} / \mathrm{OM}$ is expected since a high fraction of
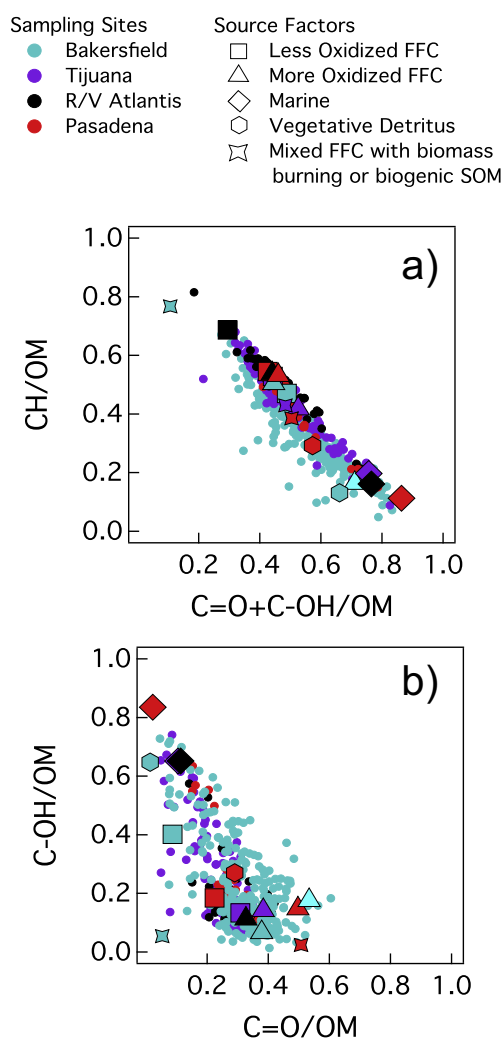

Fig. 4. Comparison of (a) unoxidized and oxidized functional group fractions of OM and (b) hydroxyl to carbonyl fraction of OM in ambient samples (circles) and PMF factors for each site. Sources identified by PMF solutions are categorized into five classes, less oxidized FFC (squares), more oxidized FFC (triangles), marine (diamonds), vegetative detritus (pentagons), and mixed FFC and biomass burning or biogenic SOM (stars). 
hydroxyl group mass is characteristic of primary marine and vegetative sources whereas carbonyl group fraction increases with secondary aerosol formation. The Marine factors correlate well with sodium and chloride in submicron particles measured by XRF (Tijuana and R/V Atlantis). The organic hydroxyl groups found in the Marine factors are likely derived from polysaccharides concentrated on the ocean surface (Aluwihare et al., 1997; Russell et al., 2010). The similarity of the OFG composition of the Marine factor with the Vegetative Detritus factor found at Bakersfield is consistent with the saccharide-like composition of plant materials (Bianchi et al., 1993). Both the Marine and Vegetative Detritus factors have double peaks in absorbance at 2929 and $2855 \mathrm{~cm}^{-1}$, characteristic of methylene peaks from longer chain hydrocarbons, which are present in waxes associated with plant materials (Hawkins and Russell, 2010).

The fifth factor found at three of the CalNex and Cal-Mex sites contains a large carbonyl or carboxylic acid group fraction and is related to mixtures of FFC emissions and biomass burning (Tijuana) or biogenic SOM (Pasadena and Bakersfield). The clear differences in OFG composition of these three factors reflects local influences of vegetation and anthropogenic activities, but the substantial alkane absorption at $2835-2980 \mathrm{~cm}^{-1}$ suggests a fossil fuel contribution to all of these factors. The similarities in the oxidized organic functional groups in these factors are evident in their proximity in Fig. 4.

\subsection{Comparison of fuel standard and fossil fuel factor organic functional groups}

Gentner et al. (2012) reviewed and quantified the similarities in individual molecular species identified in fuel and OM composition in tunnel studies, as well as Bakersfield, showing that total aliphatic compounds constitute the $58 \%$ and $68 \%$ carbon by weight of gasoline and diesel, respectively. Here, we use the alkane absorption region of FTIR spectra $\left(2835-2980 \mathrm{~cm}^{-1}\right)$ to look for similarities between the composition of the observed OM and fuel standards. While FTIR spectroscopy cannot resolve the individual compounds, the spectral signature is characteristic of the mixture. Fig. 5 shows a comparison of the CalNex and Cal-Mex FFC factors to four fuel standards: gasoline, diesel, oil, and ship diesel. One interesting aspect of this comparison is that almost all of the fossil fuel OM factors at the four sites have at least three of the four characteristic peak locations $\left(2954,2923,2869\right.$, and $\left.2855 \mathrm{~cm}^{-1}\right)$ in common with the fuel standards. The ratios of the four common peaks differ in height, as summarized for the fuels and the factors in Table 2.

Comparing the peak ratios of the factors to the fuels, we see that the alkane region in the FF1 factor found at Tijuana is most similar to the motor oil signature. This local contribution is consistent with the older vehicle fleet in Tijuana than in the U.S. cities (Takahama et al., 2013a). The spectra of the Nighttime OA factor found at Bakersfield and the BB (mixed) factor at Tijuana are both quite

Bakersfield

Tijuana

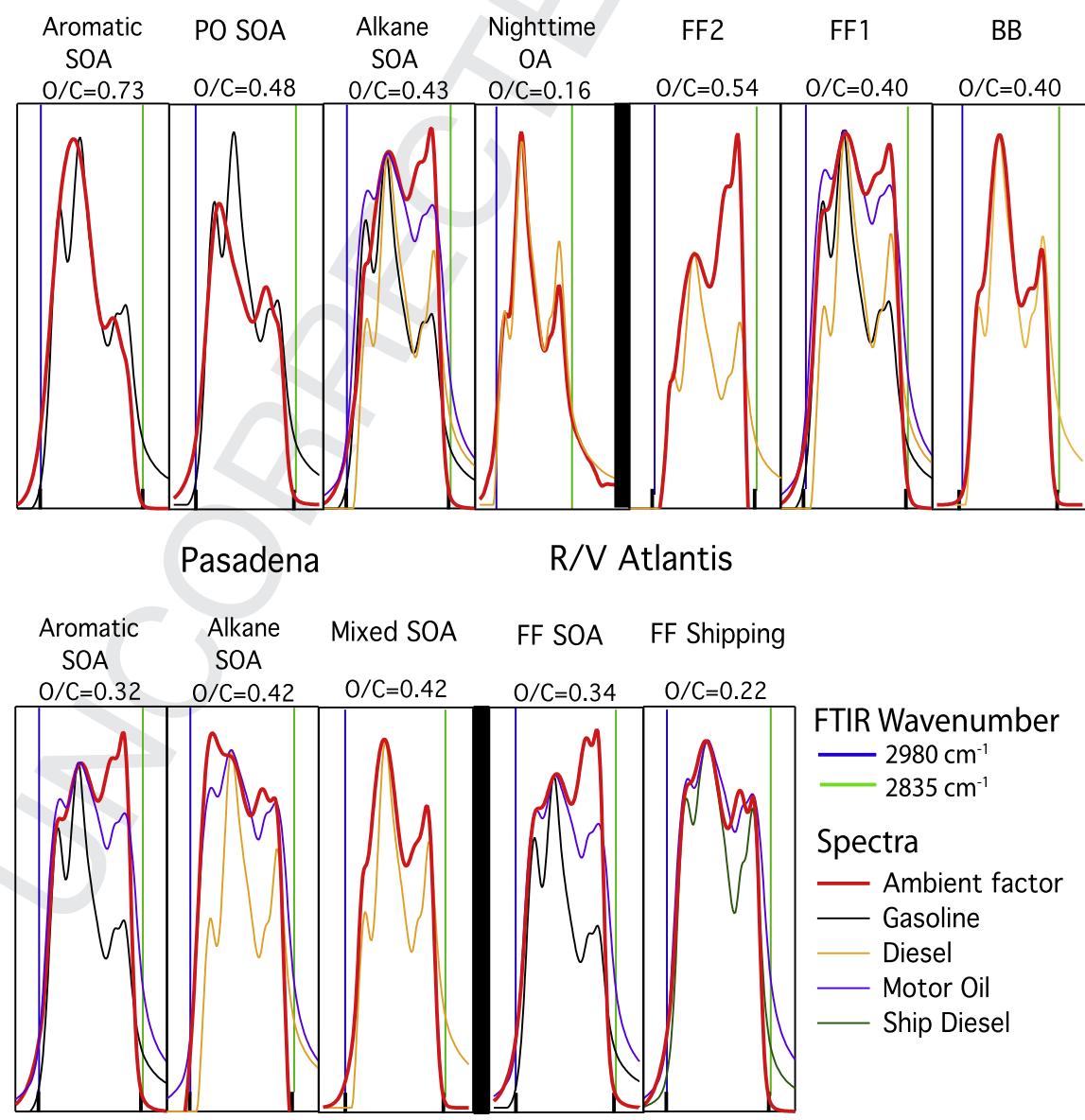

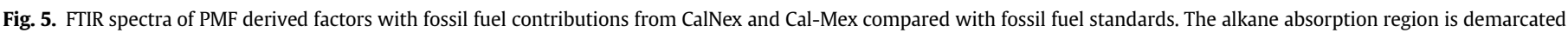

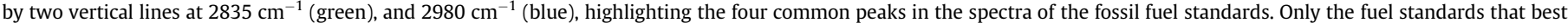

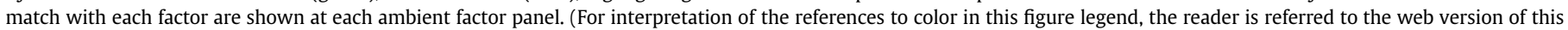
article.) 
Table 2

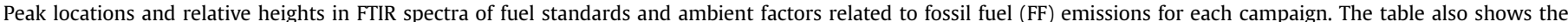

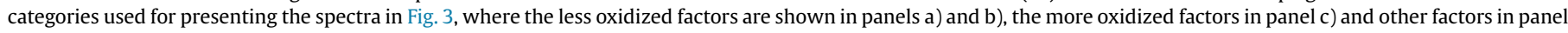
f).

\begin{tabular}{|c|c|c|c|c|c|c|c|}
\hline & \multirow[t]{2}{*}{ Less oxidized } & \multirow[t]{2}{*}{ More oxidized } & \multirow[t]{2}{*}{ Other } & \multicolumn{4}{|c|}{ Height at peak locations ${ }^{\mathrm{a}, \mathrm{b}}$} \\
\hline & & & & $2954 \mathrm{~cm}^{-1}$ & $2923 \mathrm{~cm}^{-1}$ & $2869 \mathrm{~cm}^{-1}$ & $2855 \mathrm{~cm}^{-1}$ \\
\hline \multirow[t]{4}{*}{ Fuel standards } & Gasoline & & & 0.80 & 1 & 0.50 & 0.60 \\
\hline & Diesel & & & 0.50 & 1 & 0.50 & 0.70 \\
\hline & Ship diesel & & & 0.80 & 1 & 0.70 & 0.80 \\
\hline & Motor oil & & & 0.90 & 1 & 0.80 & 0.90 \\
\hline \multirow[t]{4}{*}{ Bakersfield } & PO (Petroleum Operations) SOA & & & $1^{\mathrm{b}}$ & - & 0.71 & 0.60 \\
\hline & & Alkane SOA & & 0.68 & 1 & 0.97 & 1.07 \\
\hline & & Aromatic SOA & & - & 1 & 0.50 & 0.40 \\
\hline & & & Nighttime OA & 0.51 & 1 & 0.45 & 0.59 \\
\hline \multirow[t]{3}{*}{ Pasadena } & Aromatic SOA & & & 1.06 & 1 & 0.93 & 0.91 \\
\hline & & Alkane SOA & & 0.83 & 1 & 1.01 & 1.09 \\
\hline & & & Mixed SOA & 0.64 & 1 & 0.71 & 0.82 \\
\hline \multirow[t]{3}{*}{ Tijuana } & FF1 & & & 0.8 & 1 & 0.89 & 0.97 \\
\hline & & FF2 & & 1.32 & 1 & 1.18 & 1.32 \\
\hline & & & BB (Biomass Burning) & 0.56 & 1 & 0.58 & 0.69 \\
\hline \multirow[t]{2}{*}{$\mathrm{R} / \mathrm{V}$ Atlantis } & FF Shipping & & & 0.90 & 1 & 0.86 & 0.90 \\
\hline & & FF SOA & & 0.90 & 1 & 1.12 & 1.14 \\
\hline
\end{tabular}

a Peak locations range from 2948 to $2956 \mathrm{~cm}^{-1}, 2921$ to $2934 \mathrm{~cm}^{-1}, 2869$ to $2877 \mathrm{~cm}^{-1}$, and 2854 to $2858 \mathrm{~cm}^{-1}$.

b The height is relative to the peak located at $2923 \mathrm{~cm}^{-1}$, except for the Petroleum Operation factor in Bakersfield which is relative to the peak located at $2948 \mathrm{~cm}$.

similar to the diesel fuel spectrum with an almost exact match in three of the four relative peak heights and widths and only a small difference at the $2855 \mathrm{~cm}^{-1}$ peak, suggesting a large contribution from at least partially unreacted (primary) diesel. Since the San Joaquin Valley (SVJ), which encompasses the CalNex short-term site and the CARB long-term site at Bakersfield, has lower population density than the LA basin but a substantial amount of transvalley transport of produce and other goods from San Francisco to LA, it is not surprising that diesel is a larger contributor in SV than LA. Using the fuel emission factors of non-combusted gas phase OC in vehicular exhaust of $0.38 \mathrm{gC} \mathrm{L}^{-1}$, the yield of SOM formation per unburned fuel mass emission of $0.15 \mathrm{gSOM} \mathrm{g}^{-1}$, and the total annual sales of diesel in Kern and LA county (Gentner et al., 2012), diesel was calculated to be responsible for $16.9 \%$ of FFC SOM formation in Kern county in contrast with $5.3 \%$ in LA basin. For Tijuana, the similarity may also arise from a nighttime contribution of unoxidized diesel traffic emissions, since this factor was frequently high at night; although it is also possible that diesel was used as part of trash burning activities. For the R/V Atlantis, the high peak at $2854 \mathrm{~cm}^{-1}$ of the less oxygenated factor is consistent with a contribution from the ship-type diesel. The factors at Pasadena are generally more mixed so that the signature of a particular fuel is not clear, but the relative height of the peak at $2855 \mathrm{~cm}^{-1}$ in the Mixed SOA factor certainly suggests that diesel emissions contribute part of the SOM formation. This is consistent with the small but nonnegligible contribution of 5.3\% estimated by Gentner et al. (2012) but contrasts with other studies that found that diesel contributions to SOM were below detection (Bahreini et al., 2011; Hayes et al., 2013).

\subsection{Contributions of primary and secondary $O M$}

Liu et al. (2011) reviewed methods used for attributing OM as secondary, showing that one of the most prevalent approaches is to define oxygen-containing mass fragments or oxidized functional groups as secondary. For FFC sources, there is little reason to doubt this is true, since oxidized organic functional groups in partially combusted, low-volatility $\left(>C_{3}\right)$ carbonyls are less th $\bar{\equiv}$ of the alkane group in $\mathrm{OM}$ identified in engine emissions (Jakober et al.,

Q2 2008). However, primary marine and terrestrial biological sources, as well as biomass burning sources, may have substantial oxygen content (Jimenez et al., 2009; Takahama et al., 2011). For this reason, the following discussion of separation of primary and secondary components has been applied only to the OM associated with the FFC sources.

There were twelve FFC factors identified at the four CalNex and Cal-Mex intensive campaigns (shown in Fig. 3). Only one of these factors (Nighttime OA factor at Bakersfield) had O/C close to 0.1, a frequently-used cutoff for identification of a purely primary, hydrocarbon-like OA (HOA), meaning that Tijuana, R/V Atlantis, and Pasadena had no factors that could be identified as POM and Bakersfield had only one POM-like factor that represented less than $10 \%$ of OM. Since PMF factors are identified by covariation of functional groups with each other, it is not surprising that rapid formation of SOM on time scales faster than captured by PMF of multi-hour filter samples may group the immediate POM with SOM that forms within a few hours - especially in an air basin with substantial mixing. This means that we cannot rule out that some fraction of the factors with $\mathrm{O} / \mathrm{C}$ greater than 0.1 might be primary. To account for this possibility, we could identify the alkane group fraction of each FFC factor as primary. This calculation represents an upper bound $\left(\mathrm{POM}_{\mathrm{ub}}\right)$, since most secondary organic products of alkanes contain $70 \%, 90 \%$ (molar) alkane groups, and even aromatic products can retain up to $30 \%$ alkane groups (Russell et al., 2011). Then as a lower bound, we can calculate the primary OM $\left(\mathrm{POM}_{\mathrm{lb}}\right)$ as the alkane group mass in excess of that expected for alkane-derived, second-generation SOA (mole fraction 0.73) (Russell et al., 2011). We consider this a lower bound because aromatic SOM and third and higher generation alkane SOM would have a lower mole fraction of alkane group.

Between these upper and lower bounds, we consider a value of 0.50 as the mole fraction of alkane group associated with FFC SOM to provide the best estimate of urban FFC SOM. This leads to a best estimate of POM $\left(\mathrm{POM}_{\mathrm{be}}\right)$ as the alkane group in excess of 0.5 mole fraction of the FFC factor. Based on the best estimates, POM accounts for $16-20 \%$ of the OM at the CalNex and Cal-Mex urban sites (Table 3). The estimate for Pasadena of $16 \%$ (for particles smaller than $2.5 \mu \mathrm{m}$ ) is consistent with the $12-17 \%$ contributions of fossil fuel hydrocarbon-like organic aerosol (HOA) and local organic aerosol (LOA) identified by (Hayes et al., 2013) with AMS-based PMF (for particles smaller than nominal $1 \mu \mathrm{m}$ cutoff). SOM from fossil fuel sources was calculated as the complement of the POM, i.e. the sum of all the oxygenated functional groups in the FFC OM factors. Since the ratio of $\mathrm{OM}$ to $\mathrm{OC}$ is different for primary and 
Table 3

Comparison of methods for estimating primary and secondary fossil fuel contributions to OM and OC (in $\mu \mathrm{g} \mathrm{m}^{-3}$ and percent of total OM and OC, respectively).

\begin{tabular}{|c|c|c|c|c|c|c|c|c|}
\hline & \multicolumn{2}{|c|}{ PMF-based method (OM) } & \multicolumn{2}{|c|}{ CO-based method ${ }^{\mathrm{b}}$} & \multicolumn{2}{|c|}{ PMF-based method (OC) ${ }^{a}$} & \multicolumn{2}{|l|}{$\mathrm{EC}=$ method $^{\mathrm{c}}$} \\
\hline & $\mathrm{POM}^{\mathrm{d}}$ & $\mathrm{SOM}^{\mathrm{d}}$ & POM & SOM & $\mathrm{POC}^{\mathrm{d}}$ & $\operatorname{SOC}^{\mathrm{d}}$ & POCV & $\mathrm{SOC}^{\mathrm{e}}$ \\
\hline Bakersfield & $0.47(19 \%)$ & $1.50(62 \%)$ & $1.52(90 \%)$ & $0.84(10 \%)$ & $0.37(30 \%)$ & $0.68(58 \%)$ & $\mathbf{0 . 1 0}(11 \%)$ & $1.10(89 \%)$ \\
\hline & $0.29-0.86(12-34 \%)$ & $1.09-1.68(47-69 \%)$ & & & $0.23-0.69(19-55 \%)$ & $0.37-0.83(34-70 \%)$ & $0.09-0.11(10-12 \%)$ & $1.09-1.11(88-90 \%)$ \\
\hline Pasadena & $1.69(16 \%)$ & $5.32(49 \%)$ & $4.04(55 \%)$ & $5.85(45 \%)$ & $1.43(25 \%)$ & $2.71(47 \%)$ & $2.60(60 \%)$ & $1.69(40 \%)$ \\
\hline & $0.53-4.23(5-39 \%)$ & $3.15-6.31(29-59 \%)$ & & & $0.44-3.57(8-62 \%)$ & $0.88-3.78(15-65 \%)$ & $3.23-1.97(46-75 \%)$ & $2.05-3.31(25-54 \%)$ \\
\hline Tijuana & $\begin{array}{c}\mathbf{0 . 6 8}(20 \%) \\
0.44-1.22(13-36 \%)\end{array}$ & $\begin{array}{c}1.41(42 \%) \\
0.87-1.65(26-49 \%)\end{array}$ & $\mathbf{3 . 1 9}(100 \%)$ & $\mathbf{0}(0 \%)$ & $\begin{array}{c}\mathbf{0 . 6 0}(32 \%) \\
0.38-1.09(20-58 \%)\end{array}$ & $\begin{array}{c}\mathbf{0 . 7 3}(39 \%) \\
0.24-0.95(13-51 \%)\end{array}$ & $\begin{array}{c}\mathbf{0 . 3 3}(25 \%) \\
0.22-0.44(17-33 \%)\end{array}$ & $\begin{array}{c}1.35(75 \%) \\
1.24-1.46(67-83 \%)\end{array}$ \\
\hline
\end{tabular}

b The CO-based method uses the FFC factors at each site.

c The EC-based method uses regression to EC (Lim and Turpin, 2002).

d Ranges correspond to the upper and lower bounds. Non-fossil fuel OM are not listed, so sums are less than $100 \%$ (see Supplemental material).

e Ranges indicate the 95\% interval of confidence.

secondary organic components, we used the functional group composition to calculate primary $\mathrm{OC}$ (POC) and secondary OC (SOC) for the PMF-based method. As expected, the POC fraction of OC is higher than the POM fraction of OM since the oxygen in oxidized organic functional groups (which are higher in SOM than POM) is excluded from SOC but not SOM.

Bahreini et al. (2011) used the ratio of $\Delta \mathrm{OM} / \Delta \mathrm{CO}$ as an indicator of secondary contributions to $\mathrm{OM}$, since $\mathrm{CO}$ tracks emissions. Increases in the amount of OM per CO are inferred to be driven by post-emission (secondary) formation. Fig. 6 shows the relationship between OM, POM, and SOM with CO. Interestingly, the Tijuana campaign shows a very low ratio of either $\mathrm{POM}_{\mathrm{ub}}$ or $\mathrm{POM}_{\mathrm{lb}}$ to $\mathrm{CO}$, consistent with the finding that most of the OM measured at this site on the northwestern edge of Tijuana was aged and transported (Takahama et al., 2013a). The slopes of $\mathrm{POM}_{\mathrm{ub}}$ with CO for Bakersfield and Pasadena are more comparable to those reported in the literature (De Gouw and Jimenez, 2009), and their correlation coefficients are slightly higher although still weak $(0.47<r<0.52)$. The wide scatter in $\Delta \mathrm{OM} / \Delta \mathrm{CO}$ is also consistent with the expected difference in diesel and gasoline usage on weekdays and weekends. However, if we use the ICARTT-based correlations of POM to CO to estimate POM as suggested by Bahreini et al. (2011), the primary contribution is 55\% at Pasadena and $90 \%$ at Bakersfield, with no reasonable estimate possible for Tijuana since the $\mathrm{C} \equiv$ elow the nominal range (making all OM appear to be primary)

Lim and Turpin (2002) proposed that POC could be quantified by its co-emission with EC, where this method was shown to be quite effective downwind of a single large urban area. We applied this approach to the CalNex and Cal-Mex ground sites in Fig. 6d, and for comparison we included the POC from the PMF-based approach. The EC-based results for Bakersfield (11\%) and Tijuana (25\%) indicate that POC is lower than PM $\equiv$ ed estimates (30\% and $32 \%$, respectively), but higher $(60 \%)$ at $\bar{r}$ asadena (compared to the PMFbased estimate of 25\%). The EC-based and CO-based estimates are most similar for Pasadena, although both indicate primary FFC organic contributions that are much higher than can be accounted for by either FTIR or AMS-based PMF of organic composition (Liu et al., 2012; Hayes et al., 2013).

A clear result is that there are significant differences in the estimated relationship between primary organic contributions and either CO or EC at the three CalNex and Cal-Mex ground sites. Both methods require the ratio of primary organic components to combustion tracers ( $\mathrm{CO}$ or EC) to be constant for all substantial sources in the region. Lim and Turpin (2002) noted this constraint and applied the approach to a case in which they were following a plume downwind of a city for quite some distance. It is consequently in keeping with their findings that the near-source urban measurements investigated here with multiple source regions and different emission profiles have different amounts of POM emitted per CO and EC. However, in contrast to studies that have assumed that the POM to $\mathrm{CO}$ ratio is invariant for different locations (Bahreini et al., 2011), we find there is no evidence to sup $\equiv$ hat approach even within the CalNex and Cal-Mex region (Fig. $\overline{\bar{y} \text { ). }}$

\section{Conclusions}

The four CalNex and Cal-Mex sites considered here (R/V Atlantis, Tijuana, Bakersfield, and Pasadena) provided intensive measurements of organic particle composition and sources. The OC concentrations were comparable to the measurements at nearby long term monitoring sites during the summer of 2010, which were typically lower than the wintertime concentrations, due to meteorological differences as well as the lower summertime contributions of biomass burning.

The CalNex and Cal-Mex sites (R/V Atlantis, Tijuana, Bakersfield, and Pasadena) showed similar OFG composition for the twelve FFC factors identified, with all reflecting contributions with both more and less oxidized organic components. The coastal measurements on the R/V Atlantis, Tijuana, and Pasadena also had primary marine biological contributions, while Bakersfield and Pasadena showed terrestrial biological vegetative detritus sources. The three land sites also had contributions from cooking (Pasadena, Bakersfield) and biomass burning activities (Tijuana). The similarity of the factor spectra for each source type across all four sites is striking, indicating that all four sites had similar types of sources, even though they contributed to ambient OM in different amounts. The similarities in the fossil fuel combustion factors are interesting in that they clearly include both more and less oxidized components at each site - with their spectral shapes indicating that different oxidized organic functional groups are associated with higher $\mathrm{O} / \mathrm{C}$. These differences are reflected in the higher fractions of hydroxyl groups in the less oxidized fossil fuel factors and in the higher fractions of carbonyl groups in the more oxidized fossil fuel combustion factors at all sites. The nearly linear alignment of the ambient samples in the functional group plot may be largely incidental, in that there is no direct evidence for progression from the less oxidized to the more oxidized factors. Such a result could also be explained by mixing primary and secondary organic components in different ratios.

Comparison of the FFC factors to FTIR spectra of diesel, gasoline, motor oil, and ship diesel shows interesting differences in the alkane group peaks. These differences may reflect either a primary contribution to the factors or the persistent FTIR absorbance signature of aliphatic hydrocarbon (alkane) precursors. In the Bakersfield Nighttime OA factor, the colder temperatures and lack of photochemical degradation produced a strong similarity between the factor alkane group absorbance and that of diesel fuel, 

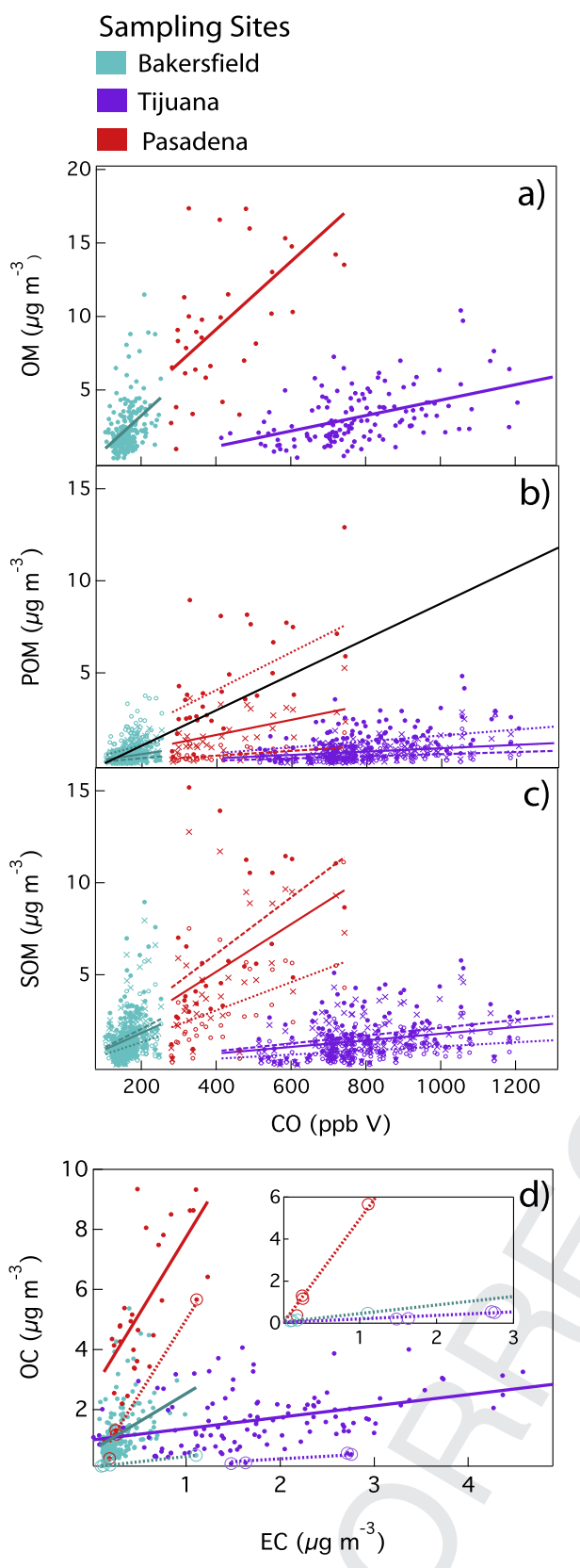

Fig. 6. Comparison of estimated primary and secondary organic component relationships to CO and EC. Panels (a), (b), and (c) show the estimated primary (POM) and secondary (SOM) organic mass plotted as a function of $\mathrm{CO}$ (carbon monoxide), for Bakersfield, Pasadena, and Tijuana. Panels (a), (b) and (c) show $\Delta \mathrm{OM} / \Delta \mathrm{CO}, \Delta \mathrm{POM} / \Delta \mathrm{CO}$, and $\Delta \mathrm{SOM} / \Delta \mathrm{CO}$ ratios, respectively. POM and SOM best estimate ratios $\left(\Delta \mathrm{POM}_{\text {be }} / \Delta C \mathrm{CO}\right.$, $\left.\Delta \mathrm{SOM}_{\mathrm{be}} / \Delta \mathrm{CO}\right)$ are depicted in solid lines. POM upper boundary and SOM lower boundary ratios are shown in short-dashed lines, while POM lower boundary and SOM upper boundary ratios are denoted in long-dashed lines. Each pair of estimates account for the total FFC OM. Panel (d) shows OC/EC ratios (solid line) and POC/EC (dashed line) based on the lowest four OC/EC observed ratios. Inset shows only the lowest four OC/ EC ratios, in circles, used to determine FFC POC.

suggesting a nighttime contribution of primary OM emissions from trucking in the San Joaquin Valley.

Using the functional group composition, we have estimated the primary contribution to the FFC factors from the alkane group mass contribution. These estimates indicate that $16-20 \%$ of OM $(25-32 \%$ of $\mathrm{OC}$ ) is from primary fossil fuel emissions at Bakersfield, Tijuana, and Pasadena (the CalNex and Cal-Mex ground-based sites). These estimates are two to five times lower than estimates based on a fixed ratio to $\mathrm{CO}$ emissions. While it is not surprising that the

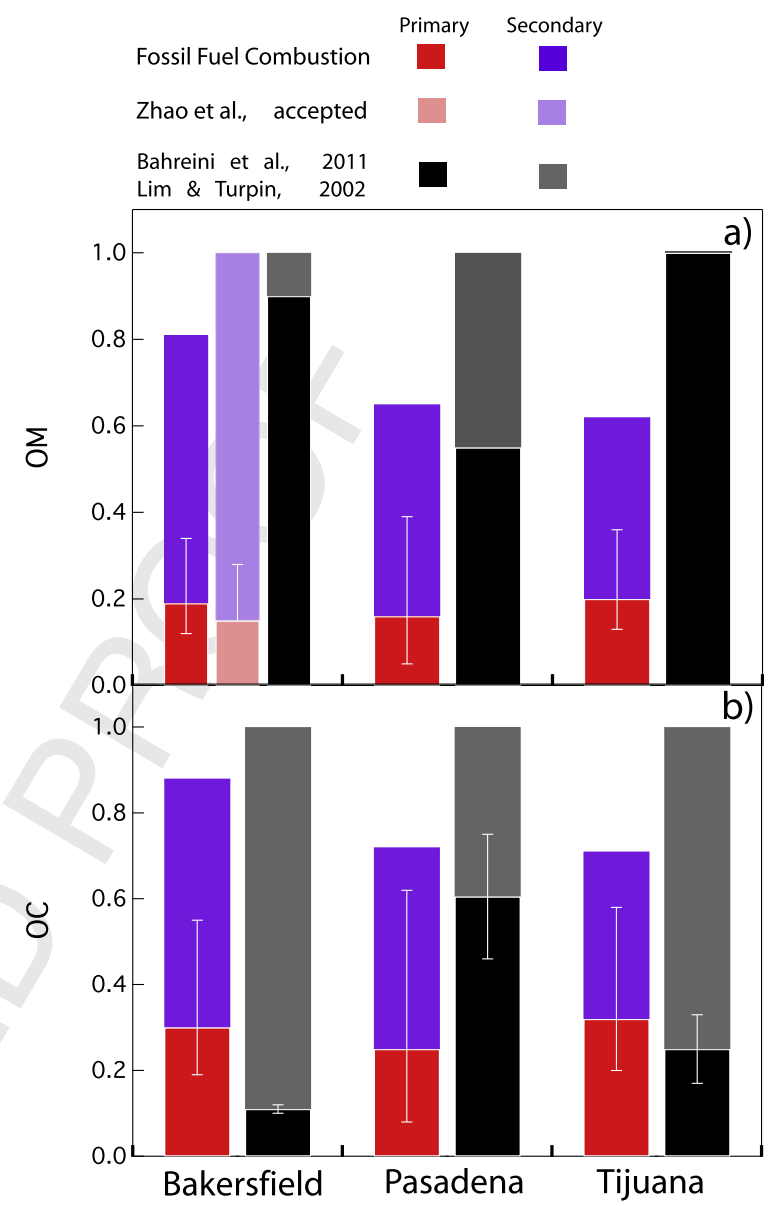

Fig. 7. Comparison of methods for estimating primary and secondary organic carbon and organic mass at the CalNex and Cal-Mex ground sites at Bakersfield, Pasadena, and Tijuana. Bars on the right are based on Lim and Turpin (2002) in panel a and on Bahreini et al. (2011) in panel b. Bars on the left show estimates calculated from PMFbased FFC factors, whereas values suggested by Zhao et al. (2013) in Bakersfield are shown in the bar in the middle of panel a.

amount of POM associated with CO differs substantially at locations with different source emissions and vehicle fleets, this has important implications for using this ratio to separate primary and secondary sources. There is also a clear indication that in summer the secondary contribution from fossil fuel sources is $42-62 \%$ of OM (with the remaining $19-38 \%$ being from biological sources, including biogenic secondary components, vegetative detritus, biomass burning, and cooking activities). The fraction on an $\mathrm{OC}$ basis favors the primary fraction more since the non-carbon mass is excluded but still gives primary OC less than $25 \chi^{32 \%}$

\section{$\Lambda^{\text {Acknowledgments }}$}

The authors appreciate financial support from the California Air Resources Board (CARB 09-328) and the National Science Foundation (NSF AGS-1009408). Additionally, we would like to thank the UC MEXUS-CONACyT Agreement of Cooperation in Higher Education and Research for the support provided to JGM. The Pasadena SP2 measurements were supported by the UK Natural Environment Research Council through a PhD studentship and the project Multiscale Chemical Composition of Carbonaceous particles and Coatings (MC4) [Grant ref: NE/H008136/1. The authors are also grateful to John Karlik and the Kern County University of California Cooperative Extension staff for support at Bakersfield, to Luisa Molina 
and the Molina Center for support at Tijuana, to Jason Surratt and Caltech for support at Pasadena, and Patricia Quinn and PMEL for support on the R/V Atlantis. In addition, we would like to thank CARB scientists Nehzat Motallebi, Eileen McCauley, and Scott Scheller for their contributions to this project. The statements and conclusions in this paper are those of the researchers (contractor) and not necessarily those of CARB. The mention of commercial products, their source, or their use in connection with material reported herein is not to be construed as actual or implied endorsement of such products.

\section{Appendix A. Supplementary data}

Supplementary data related to this article can be found at http:// dx.doi.org/10.1016/j.atmosenv.2013.08.047.

\section{References}

Aluwihare, L.I., Repeta, D.J., Chen, R.F., 1997. A major biopolymeric component to dissolved organic carbon in surface sea water. Nature 387 (6629), 166-169. http://dx.doi.org/10.1038/387166a0.

Bahreini, R., et al., 2011. Gasoline emissions dominate over diesel in formation of secondary organic aerosol mass. Geophys. Res. Lett. 39. http://dx.doi.org/ 10.1029/2011gl050718.

Bianchi, G., Gamba, A., Limiroli, R., Pozzi, N., Elster, R., Salamini, F., Bartels, D., 1993. The unusual sugar composition in leaves of the resurrection plant Myrothamnus flabellifolia. Physiol. Plant 87 (2), 223-226. http://dx.doi.org/10.1034/j.13993054.1993.870215.x.

Cass, G.R., 1998. Organic molecular tracers for particulate air pollution sources Trends Analyt. Chem. 17 (6), 356-366. http://dx.doi.org/10.1016/s01659936(98)00040-5.

Day, D.A., Liu, S., Russell, L.M., Ziemann, P.J., 2010. Organonitrate group concentrations in submicron particles with high nitrate and organic fractions in coastal southern California. Atmos. Environ. 44 (16), 1970-1979. http://dx.doi.org 10.1016/j.atmosenv.2010.02.045.

De Gouw, J., Jimenez, J.L., 2009. Organic aerosols in the earth's atmosphere. Environ. Sci. Technol. 43 (20), 7614-7618. http://dx.doi.org/10.1021/Es9006004.

de Gouw, J.A., et al., 2005. Budget of organic carbon in a polluted atmosphere: results from the New England air quality study in 2002. J. Geophys. Res. Atmos. 110 (D16). http://dx.doi.org/10.1029/2004jd005623.

Gentner, D.R., et al., 2012. Elucidating secondary organic aerosol from diesel and gasoline vehicles through detailed characterization of organic carbon emissions. Proc. Natl. Acad. Sci. U. S. A. 109. http://dx.doi.org/10.1073 pnas.1212272109.

Gilardoni, S., et al., 2007. Regional variation of organic functional groups in aerosol particles on four US east coast platforms during the International Consortium for Atmospheric Research on Transport and Transformation 2004 campaign. J. Geophys. Res. Atmos. 112 (D10). http://dx.doi.org/10.1029/2006jd007737.

Hawkins, L.N., Russell, L.M., 2010. Oxidation of ketone groups in transported biomass burning aerosol from the 2008 northern California lightning series fires. Atmos. Environ. 44, 4142-4154. http://dx.doi.org/10.1016 j.atmosenv.2010.07.036.

Hawkins, L.N., Russell, L.M., Covert, D.S., Quinn, P.K., Bates, T.S., 2010. Carboxylic acids, sulfates, and organosulfates in processed continental organic aerosol ove the-goutheast Pacific Ocean during VOCALS-REx 2008. J. Geophys. Res. Atmos. 三

Hayes, P.L., Ortega, A.M., Cubison, M.J., Froyd, K.D., Zhao, Y., Cliff, S.S., Hu, W.W. Toohey, D.W., Flynn, J.H., Lefer, B.L., Grossberg, N., Alvarez, S., Rappenglück, B., Taylor, J.W., Allan, J.D., Holloway, J.S., Gilman, J.B., Kuster, W.C., de Gouw, J.A., Massoli, P., Zhang, X., Liu, J., Weber, R.J., Corrigan, A.L., Russell, L.M., Isaacman, G., Worton, D.R., Kreisberg, N.M., Goldstein, A.H., Thalman, R. Waxman, E.M., Volkamer, R., Lin, Y.H., Surratt, J.D., Kleindienst, T.E. Offenberg, J.H., Dusanter, S., Griffith, S., Stevens, P.S., Brioude, J., Angevine, W.M., Jimenez, J.L., 2013. Organic Aerosol Composition and Sources in Pasadena California During the 2010 CalNex Campaign (in press) http://dx.doi.org/10. 1002 /jgrd.50530.

Jimenez, J.L., et al., 2009. Evolution of organic aerosols in the atmosphere. Science 326 (5959), 1525-1529. http://dx.doi.org/10.1126/science.1180353.

Johnson, D., Utembe, S.R., Jenkin, M.E., Derwent, R.G., Hayman, G.D., Alfarra, M.R. Coe, H., McFiggans, G., 2006. Simulating regional scale secondary organic aerosol formation during the TORCH 2003 campaign in the southern UK. Atmos. Chem. Phys. 6, 403-418

Lim, H.J., Turpin, B.J., 2002. Origins of primary and secondary organic aerosol in Atlanta: results' of time-resolved measurements during the Atlanta supersite experiment. Environ. Sci. Technol. 36 (21), 4489-4496. http://dx.doi.org 10.1021/Es0206487.

Liu, D., et al., 2010. Single particle characterization of black carbon aerosols at a tropospheric alpine site in Switzerland. Atmos. Chem. Phys. 10 (15), 7389-7407. http://dx.doi.org/10.5194/Acp-10-7389-2010.
Liu, S., Takahama, S., Russell, L.M., Gilardoni, S., Baumgardner, D., 2009. Oxygenated organic functional groups and their sources in single and submicron organic particles in MILAGRO 2006 campaign. Atmos. Chem. Phys. 9 (18), 6849-6863.

Liu, S., Day, D.A., Shields, J.E., Russell, L.M., 2011. Ozone-driven daytime formation of secondary organic aerosol containing carboxylic acid groups and alkane groups. Atmos. Chem. Phys. 11 (16), 8321-8341. http://dx.doi.org/10.5194/acp-11-83212011.

Liu, S., et al., 2012. Secondary organic aerosol formation from fossil fuel sources contribute majority of summertime organic mass at Bakersfield. J. Geophys. Res. 117 (D24). http://dx.doi.org/10.1029/2012JD018170.

Lu, R., Turco, R.P., 1995. Air pollutant transport in a coastal environment. 2. 3dimensional simulations over Los-Angeles Basin. Atmos. Environ. 29 (13), 1499-1518. http://dx.doi.org/10.1016/1352-2310(95)00015-0.

McMeeking, G.R., Hamburger, T., Liu, D., Flynn, M., Morgan, W.T., Northway, M., Highwood, E.J., Krejci, R., Allan, J.D., Minikin, A., Coe, H., 2010. Black carbon measurements in the boundary layer over western and northern Europe. Atmos. Chem. Phys. 10 (19), 9393-9414. http://dx.doi.org/10.5194/Acp-109393-2010.

Molina, M.J., Ivanov, A.V., Trakhtenberg, S., Molina, L.T., 2004. Atmospheric evolution of organic aerosol. Geophys. Res. Lett. 31 (22). http://dx.doi.org/10.1029/ 2004gl020910.

Paatero, P., Tapper, U., 1994. Positive matrix factorization - a nonnegative factor model with optimal utilization of error-estimates of data values. Environmetrics 5 (2), 111-126. http://dx.doi.org/10.1002/env.3170050203.

Robinson, A.L., Donahue, N.M., Shrivastava, M.K., Weitkamp, E.A., Sage, A.M., Grieshop, A.P., Lane, T.E., Pierce, J.R., Pandis, S.N., 2007. Rethinking organic aerosols: semivolatile emissions and photochemical aging. Science 315 (5816), 1259-1262. http://dx.doi.org/10.1126/science.1133061.

Russell, L.M., Takahama, S., Liu, S., Hawkins, L.N., Covert, D.S., Quinn, P.K., Bates, T.S., 2009. Oxygenated fraction and mass of organic aerosol from direct emission and atmospheric processing measured on the R/V Ronald Brown during TEXAQS/GoMACCS 2006. J. Geophys. Res. Atmos. 114. http://dx.doi.org/10.1029/ 2008jd011275.

Russell, L.M., Hawkins, L.N., Frossard, A.A., Quinn, P.K., Bates, T.S., 2010. Carbohydrate-like composition of submicron atmospheric particles and their production from ocean bubble bursting. Proc. Natl. Acad. Sci. U. S. A. 107 (15), 66526657. http://dx.doi.org/10.1073/Pnas.0908905107.

Russell, L.M., Bahadur, R., Ziemann, P.J., 2011. Identifying organic aerosol sources by comparing functional group composition in chamber and atmospheric particles. Proc. Natl. Acad. Sci. U. S. A. 108 (9), 3516-3521. http://dx.doi.org/10.1073/ pnas.1006461108.

Schwarz, J.P., et al., 2010. The detection efficiency of the single particle soot photometer. Aerosol Sci. Tech. 44 (8), 612-628. http://dx.doi.org/10.1080/ 02786826.2010 .481298 .

Sorooshian, A., et al., 2006. Oxalic acid in clear and cloudy atmospheres: analysis of data from international consortium for atmospheric research on transport and transformation 2004. J. Geophys. Res. Atmos. 111 (D23). http://dx.doi.org/ 10.1029/2005jd006880.

Subramanian, R., Kok, G.L., Baumgardner, D., Clarke, A., Shinozuka, Y., Campos, T.L., Heizer, C.G., Stephens, B.B., de Foy, B., Voss, P.B., Zaveri, R.A., 2010. Black carbon over Mexico: the effect of atmospheric transport on mixing state, mass absorption cross-section, and BC/CO ratios. Atmos. Chem. Phys. 10 (1), 219-237.

Takahama, S., Schwartz, R.E., Russell, L.M., Macdonald, A.M., Sharma, S., Leaitch, W.R., 2011. Organic functional groups in aerosol particles from burning and non-burning forest emissions at a high-elevation mountain site. Atmos. Chem. Phys. 11 (13), 6367-6386. http://dx.doi.org/10.5194/acp-11-6367-2011.

Takahama, S., Johnson, A., Guzman Morales, J., Russell, L.M., Duran, R., Rodriguez, G., Zheng, J., Zhang, R., Toom-Sauntry, D., Leaitch, W.R., 2013a. Submicron organic aerosol in Tijuana, Mexico, from local and southern California sources during the CalMex campaign. Atmos. Environ. 70, 500-512. http://dx.doi.org/10.1016/ j.atmosenv.2012.07.05

Takahama, S., Johnson, A., Russell, L.M., 2013b. Quantification of carboxylic and carbonyl functional groups in organic aerosol infrared absorbance spectra. Aerosol Sci. Technol. 47, 310-325. http://dx.doi.org/10.1080/ 02786826.2012 .752065$.

Takegawa, N., Miyakawa, T., Kondo, Y., Blake, D.R., Kanaya, Y., Koike, M., Fukuda, M., Komazaki, Y., Miyazaki, Y., Shimono, A., Takeuchi, T., 2006. Evolution of submicron organic aerosol in polluted air exported from Tokyo. Geophys. Res. Lett. 33 (15). http://dx.doi.org/10.1029/2006gl025815.

Faylor, W., 2013. Black carbon-optical properties in the Los Angeles area-during GalNex 2010. Part 1: assessment of the sensitivity of the derivation of core size and coating thickness to density and refractive index and black carbon-optical properties in the Los Angeles area during CalNex 2010. J. Geophys. Res. Atmos. (submitted for publication).

Turpin, B.J., Saxena, P., Andrews, E., 2000. Measuring and simulating particulate organics in the atmosphere: problems and prospects. Atmos. Environ. 34 (18), 2983-3013. http://dx.doi.org/10.1016/s1352-2310(99)00501-4.

Volkamer, R., Jimenez, J.L., San Martini, F., Dzepina, K., Zhang, Q., Salcedo, D., Molina, L.T., Worsnop, D.R., Molina, M.J., 2006. Secondary organic aerosol formation from anthropogenic air pollution: rapid and higher than expected. Geophys. Res. Lett. 33 (17). http://dx.doi.org/10.1029/2006gl026899.

Zhao, Y., et al., 2013. Sources of organic aerosol investigated using organic compounds as tracers measured duri $=$ Nex in Bakersfield. J. Geophys. Res. Atmos. (submitted for publication). 